\title{
Shattering the Myth of Costless Price Changes
}

\author{
Mark Bergen \\ Department of Marketing and Logistics Management, CSOM \\ University of Minnesota \\ Shantanu Dutta \\ Department of Marketing \\ University of Southern California \\ Daniel Levy \\ Department of Economics \\ Bar-Ilan University and Emory University \\ Mark Ritson* \\ Department of Marketing \\ London Business School \\ Mark Zbaracki \\ The Wharton School \\ University of Pennsylvania
}

JEL Codes: M31, M10, M20, L11, L16, E31, D40, D20

Key Words: Pricing, price setting, price adjustment, cost of price adjustment, price change management, investment in pricing processes, supply chains, customer costs of price adjustment

\footnotetext{
* Corresponding author.
} 


\title{
Shattering the Myth of Costless Price Changes: Emerging Perspectives on Dynamic Pricing
}

\begin{abstract}
In this paper we argue that pricing is all about price changes, and that the costs of price changes are often simultaneously subtle and substantial. We discuss a framework to deal with the dynamics of changing prices. This framework incorporates customer interpretations of price changes, an awareness of the organizational costs of price changes, investments in future pricing processes, and an understanding of the role that supply chains play in price change strategy. The framework can be used at the tactical level to improve the specific price changes chosen and made, at the managerial level to decide whether or not to make a particular price change at all, and at the strategic level to determine what price adjustment processes should be invested in to improve pricing effectiveness in the future.
\end{abstract}




\section{Pricing In Today's Marketplace Is All About Change}

Pricing, in today's fast-paced, ever-changing marketplace, is all about change: from how to deal with new pricing formats on the Internet to how to change prices internationally in response to hyperinflation and the Euro. Firms are constantly forced to consider whether, when, and how to change their pricing. Consider the changes in Ford's pricing in the last two years, which includes how to do auctions on-line with suppliers, to adopting "smart pricing" with customers. Proctor \& Gamble chose to change its pricing structure to Every Day Low Pricing. Retailers such as Barnes $\&$ Noble and Best Buy have had to decide how to change prices in the on-line world. Meanwhile companies such as Amazon.com have experimented with "dynamic pricing" in the same ononline environment. Companies such as Abbott Laboratories, DuPont and 3M are constantly deciding when to complicate their pricing to allow more bundles and systems offerings into their pricing mix. Internationally, Daimler-Chrysler, which has had to deal with changing prices in Europe as they adopt the new currency, the Euro, and Unilever has had to adjust prices in response to hyperinflationary pressures in Brazil, Eastern Europe and Asia. From how to change prices to be more effective in e-commerce, to international issues such as the Euro and hyperinflation, to new technologies that allow yield management and smart pricing - the biggest issue most firms face in pricing today is when, and how, to change their pricing.

\section{The Myth of Costless Price Changes}

Strangely, there is little in the pricing literature to help a manager deal with the process of changing prices. We talk as if changing prices happens magically, and that there are no costs to changing prices in our firms. Studies have stated that price wars are becoming more common because managers tend to view a price change as an easy, quick, and reversible action! Essentially we live with a myth that "prices are easy and costless to change".

Yet price changes are not easy, and they are certainly not costless. Just ask Proctor and Gamble about the substantial costs of changing to an Every Day Low Price strategy for their products. There were huge internal costs associated with communicating, educating and convincing 
managers about this price change within the organization. The sales force had to be retrained to sell without promotions and the organization had to be restructured to take full advantage of this new form of pricing. $P \& G$ had to re-engineer their purchasing, engineering, manufacturing and distribution functions for value pricing to succeed. Further, it required changes in product development and the roles of both brand managers and the sales force had to be restructured. The company had to change its incentives and compensation scheme to be in line with this new form of pricing. The costs of communicating with, educating, and convincing customers were even larger. Many customers were very angry. The CEO of Stop and Shop went so far as to say that "P\&G is acting like a dictator. Like all dictators they will fall. We will do everything in our power to undermine their plan". Wholesalers were also upset. SuperValu added a special surcharge to $P \& G$ products above its regular fees, and many wholesalers discontinued or stopped merchandising $P \& G$ brands. One senior $P \& G$ manager said, "I had never in my 30 years in this business seen our customer base as angry, both in what we were doing, and in how we were doing it. "thi

Or just ask executives at Amazon.com. The customer outrage at the price changes being made by Amazon.com with their experiments in dynamic pricing was immense. The outcry was so large that they had to rescind their pricing policy immediately, and issue both public apologies and offer money back to those customers who were affected.

Internationally, just ask executives for companies selling in Europe dealing with the Euro. Jacques-Etienne de T'Serclaes, partner at PriceWaterhouseCoopers in Paris, and formerly the managing director of Euromarche, states that firms will incur "major up-front costs in implementing the changeover to the new currency". They will have to "train their workers ... modify their computer systems and checkout machines. They will have to re-price everything in their stores, and in most cases, maintain two prices for each product - the new Euro price and the old national price." Manfred Gentz, a member of the Board of Management of Daimler-Chrysler; in Stutgart Germany was appointed to lead Daimler-Chrysler's Euro initiative. Gentz stated that the costs of price changeover to the new currency has been substantial and that "Approximately 
1,500 of our employees are involved in euro-related projects, and we expect to spend DM 200

million on the changeover., i]

Even academics agree. According to the literature on the economics of price adjustment, prices are often very costly to change. Recent field studies have documented that the process of changing prices can be very expensive whether in retail markets or industrial markets. Further, the most important costs of changing prices are the time and attention required of managers to gather the relevant information and to make and implement decisions and preparing customers about the price changes

\section{Emerging Perspectives on Managing Price Changes}

Fortunately for managers, there is an emerging literature in marketing and economics that can help them know when a price change is appropriate, and how to change prices most effectively. In this paper we'll draw on that literature, and on experiences from firms who have faced the challenge of pricing, to show you how to deal more effectively with changing prices at your firm.

From e-commerce to international markets, this perspective on the dynamics of pricing offers managers new tools and perspectives to tackle the kinds of pricing challenges they'll be facing in the years ahead. We develop a framework for understanding the variety of customer, supply chain, and company aspects of changing prices. This framework is valuable at the tactical level for people making specific pricing decisions, at the managerial level where firms set up pricing processes, and at the strategic level where an understanding of pricing dynamics is critical to the long-term viability of a firm.

\section{Be Aware of the Costs of Changing Price Within Your Organization}

Changing prices can impose hidden costs throughout your firm. This may seem surprising at first, as it was to a Coca-Cola manager, who's initial reaction to this suggestion was: "they're not that 
high here", but on further reflection realized that: "the more I think about it, our costs are high" and after measuring them, found that in fact they were much larger than he had supposed.

The first inherent cost that many managers experience in changing prices is simple physical costs. These costs can be defined as the costs incurred in the actual physical act of changing prices. Originally these costs were called "menu costs" in the economics literature because they represented the literal costs of altering an existing menu of posted price $\square^{\square}$ Large retailers such as Best Buy, Target, and Tesco experience these physical costs on a weekly basis through the labor costs associated with changing thousands of shelf prices within their stores. Another way in which these costs are often experienced by firms such as 3M, Ericsson, and Xerox is through the costs of producing, printing, and distributing their price books. These costs can be substantial. In the retail grocery industry the costs of changing prices is over $\$ 100,000$ annually per store, generating millions of dollars in costs for a major chain, and taking up as much as $40 \%$ of the reported profits for some of these chains

Another source of costs are managerial costs. Managerial costs are defined as "the time and attention required of managers to gather the relevant information and to make and implement decisions. ${ }^{2}$. Typically these costs are incurred within an organization as a result of three distinct

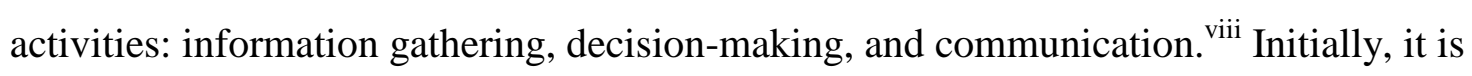
important for companies to gather information on their production and selling costs, competitive actions, and their customers' likely reactions to price changes. Usually this information resides in many places throughout an organization. Accounting and finance have the cost information, the sales force has customer and competitive information, and marketing has the other sources of customer and market information. MIS must help set up systems and software to allow managers to gather, store, evaluate and communicate this information in the company.

Second, managers need to analyze this data and evaluate the benefits of various pricing actions and reactions. Actuaries at companies like Prudential spend a great deal of time analyzing the prices of their product offerings looking at costs, actuarial tables, competitive prices, customer 
information and company goals. The process of evaluating their price changes can take months. At one company the pricing manager lamented that "the pricing season lasts longer than the NFL". Aside from the enormous amount of time, many people throughout the organization can be involved in analyzing pricing data. At Proctor and Gamble, for example, there are pricing specialists who support brand managers who make pricing decisions. Particularly large price changes must be approved by the board. Upper management also sets goals and objectives for pricing, handles internal disputes about pricing strategies, and deals with customers wanting to complain about or renegotiate prices. Upper management often has to resolve conflicting views of pricing between the corporate managers and the sales force. Another factor in the managerial analysis costs is the frequency of price change decisions. In large industrial firms, like $3 \mathrm{M}$ or Abbott Laboratories, this frequency is often annual, whereas in the retail business like Safeway, the frequency of price changes runs on a weekly basis. Price change decisions can even be made on a daily level, as is the case at American Airlines with their yield management systems. The combination of the time committed to a price change, the number of employees that are involved, and the frequency with which these decisions are made can add up to enormous managerial costs during the analysis stage.

Third, price changes have to be sold or communicated within the firm. Price changes must be communicated internally to upper management, to the sales force, and to other employees. In each case, not only must the prices themselves be communicated, but also the logic behind the change. This is partly so that members of the organization can make sense of the price change, and also because many of these employees will eventually be responsible for communicating this logic externally to customers. This communication requires preparation, and often results in long hours of discussion and education across the organization. For example, when DHL was attempting to revise its pricing, the Worldwide Sales and Marketing Director had to communicate his decisions to country managers and their staff in over 50 countries. Each country's managers had different reactions to these changes. This created an immense communication task for DHL, and its managers. 
Both physical costs and managerial costs make up the total costs of price changes within a firm. In general, despite their relative subtlety, the managerial costs dwarf the physical costs of price change and are by far the more important costs of adjustment $\frac{1}{\mathrm{x}}$ One recent study estimates managerial costs to be over six times the magnitude of the physical costs incurred in firms that were observed changing prices ${ }_{4}$ is important for managers to be aware that more visible physical costs may mask much larger managerial costs. For example, if bricks and mortar retailers such as Best Buy or Barnes and Noble were to only look at the physical costs of pricing they could easily change prices much more frequently on their web pages than in their stores. The internet, however, does not necessarily reduce the managerial costs inherent in a price change. In fact, quite the opposite was true for both Barnes and Noble and Best Buy. Their attempts to set "click" prices lower than the "brick" prices were initially plagued by internal resistance from their offline businesses fearing cannibalization. The internet can actually increase the internal organizational costs of price adjustment, due to the added complexity of dealing with e-prices and in-store pricing, the added data from people buying through web sites, and the additional knowledge and systems that are required to understand e-buying. It is a trait of many new technologies (such as electronic shelf labels, Coke's automatic vending machine, and the internet) to claim that they can lower the costs of changing price. However, these technologies actually only reduce the physical costs of changing price. It is not clear whether these technologies will lower the managerial and previously mentioned customer costs. Yet it is these costs that form the vast majority of the costs incurred in changing price.

Managers must be fully aware of the full range of managerial costs that may exist within their organizations when they change their prices. By being aware of these costs you are less likely to jump to the newest fad in pricing, and you are less likely to rely on price cuts as an initial response to competitive actions. Further, these costs may limit your company's ability to react to price changes effectively. Managers considering new pricing formats, from yield management to bundling/systems selling should be aware that the costs of changing pricing formats especially the internal organizational and customer preparation costs can be substantially higher than the costs to change prices within an existing pricing format. For example, salespeople at companies like Signode, John Deere and Abbott Laboratories complain that price change processes requires 
many levels of authorization and therefore cause large delays in the price change decisions. This is crucial because in many cases an inability to react to price changes effectively can cost lost sales. An understanding of managerial costs is critical in understanding whether a price change should be undertaken and also how it can be most effectively implemented.

\section{Be Ready to Invest in Changing the Way You Change Prices}

It would be a mistake to portray the costs of changing prices as static limitations that every manager must accommodate into their pricing strategy. Aside from identifying the current costs of changing prices, firms can also strategically modify their pricing processes in order to reduce the costs that will be incurred in future price changes. Firms can reduce the number of people involved in the pricing process, invest in systems that improve the flow of information among participants in the pricing process, and invest in training managers so that they are more effective with the time and analysis they spend on pricing. Creating more efficient pricing systems can save a firm money and simultaneously give it a competitive advantage in pricing. For example, American Airlines estimated that the cost savings it could gain by reducing its number of fares from 700,000 to 500,000 could reach $\$ 25,000,000$ annually and reinforce their position as a price leader in the market.

One of the most natural places to think about re-engineering these costs is in firms in economies facing inflation and hyperinflation. Firms in countries such as Brazil, Turkey, Eastern Europe and Asian countries such as Korea and Japan, adopt a variety of activities to reduce their costs of changing prices. In Israel in the 1980's stores would go from putting prices on each product to putting prices on a chalk board at the front of the store, by the checkout stands, so that prices could be changed more easily. Another method that Israeli bookstores invented to reduce the menu cost caused by the need to frequently adjust prices because of the hyperinflation was to group books by price groups and assign two digit code numbers to the books in each group. Afterwards, to change the prices of the books they simply altered the price that corresponded to each price group thus saving time and, more importantly, the physical costs of changing price. 
Another process to reduce the cost of adjusting prices is known as "dollarization, to the tendency in inflationary economies to post prices in foreign currency units, in this case dollars, that remain stable. As the domestic currency depreciates and thus looses value, there is a need to adjust prices upward to keep the real prices stable. If the value of the US dollar remains stable, then by quoting prices in the US dollars, the seller eliminates the need to adjust the price. The adjustment takes places automatically as the price of the US dollar in terms of the domestic currency increases. This practice of dollarization was undertaken by firms in Israel during periods of hyperinflation. Prices of durable goods, electronics, and houses were always listed in dollars, from hundreds to thousand of dollars per item. This was especially interesting given that, by law, no-one in Israel was allowed to hold more than $\$ 100$ U.S. dollars demonstrating that although the prices were listed and calculated in dollars, they were being paid for in Shekels.

It is important to note that a firm may need to invest money today in order to create more efficient pricing processes ${ }^{2}$ and thus reduce costs tomorrow. A recent study ${ }_{1 \text { ivi }}$ dentified three types of investments that firms can make to improve their pricing processes: human capital, systems capital, and social capital. Human capital refers to investments made in the knowledge and skills of employees engaged in pricing activities. For example, Abbott Laboratories developed a specific pricing training course for all the members of one of their divisions. Systems capital refers to investments made in the hardware and software used to facilitate pricing processes. For example, one major automotive supplier invested millions of dollars in new software systems to analyze the financial implications of price changes. In future years this reduced the managerial time and labor spent on price adjustment substantially. Social capital refers to investments made in the communication and organization structure and culture that unites the different participants in a particular firm involved in pricing activity. For example, a pricing manager at a major automotive manufacturer created pricing teams drawn from key participants from all over the company in order to specifically create better interactions and communication around pricing decisions. Regardless of the actual investments made, these examples highlight the rich array of potential solutions that are available to managers who attempt to improve their pricing processes and thus reduce the costs of changing price in the future. 


\section{Understand How Your Supply Chain Experiences Price Changes}

When prices are changed they can have an enormous impact on your supply chain partners. At SuperValu, the largest wholesaler in the United States, the senior pricing manager stated: "Whenever a supplier like Kraft changes their prices we have to evaluate what new price we charge our retailers, and then our retailers have to make similar calculations." Thus, a price change by Kraft created costs for their customers, like Supervalu, and their customers' customers, like Kowalskis. Essentially a price change "ripples" down through the supply chain. At one large supplier of industrial parts the management lowered its list prices, thinking that this would be well received by its customers. But many of these customers were actually upset by this price cut because their computer systems were only set up to deal with price increases. In this instance the price decrease would have proved costly because each decrease would have had to have been entered by hand into the system. Interestingly, many managers are only conscious of the costs that they incur when their supplier changes prices to them. They are not cognizant of the costs that they create for their customers when they change their prices. Many times channel efficiencies can be obtained and customer relationships can be extended when managers take a broader view of the costs of changing price throughout their supply chain.

On a more mercenary level, it is also possible for a manager to use their cognizance of the pricing change costs of their supply chain partner to their pecuniary advantage. Consider an example of the supply chain in the grocery industry. One manager at IRI used his understanding of these costs to make additional profits for his clients. He realized from his data that retailers incurred costs from small price changes and therefore wouldn't always change their retail prices in response to small price changes from the manufacturer. These sizes ranged from a nickel to a quarter depending on the product category. He counseled his clients against small price decreases because they wouldn't be passed on to the end consumers. He also supported small price increases because they wouldn't lead to higher prices for end customers. As a general rule, if you're going to lower prices be certain that there is no place in your supply chain where the costs 
of price change can become barriers to getting those price reductions to move to the end customers.

\section{Be Sensitive to Customer Interpretations of Price Changes}

Changing prices can be a source of customer frustration if they view the changes as unfair. For example, Coke recently considered using new technologies to allow their vending machines to change prices based on the temperature. Chairman Doug Ivester was quoted as telling a Brazilian magazine that people watching, say, a sports event in summer heat would naturally develop a powerful craving for a drink. "So it's fair that it should be more expensive ... The machine will simply make this process automatic." The customer reaction to this idea was swift and intensely negative. In fact, when Ivester was forced out in December, many media sources partly attributed it to the public relations fiasco. Coke immediately dropped all interest in trying these kinds of price changes.

Similarly Amazon.com began experimenting with changing prices by customer on their web site. They set higher prices to loyal customers, under the assumption that they valued Amazon's services and had a stronger relationship with Amazon. Yet once they were discovered to be changing prices this way, there was a huge public outcry with a number of loyal Amazon customers stating that they would never buy from Amazon again. Firms such as Eddie Bauer and Fingerhut have faced similar problems when they have set different prices on their catalog versus their prices on the web. They are concerned that customers will be frustrated to see different prices between the two formats. So if it doesn't make sense to change prices on the catalogue it won't be done on the web.

Price changes can also be perceived as unfair by customers during periods of currency changes. For instance, Jacques-Etienne de T'Serclaes, partner at Price Waterhouse Coopers in Paris, and formerly the managing director of Euromarche, talking about the European conversion to the Euro, states that "The way shoppers behave when confronted with the new currency will have immediate and lasting repercussions for retailers, managers and the entire European economy." 
He suggests that the new currency will "disorient people", have a "strong psychological impact", and that customers "will be suspicious that retailers are using rounding to cheat them".

It is clear from these examples that a manager must be able to predict how different markets will react to your price changes. This means more than simple estimates. It means using lead users, market research, previous price changes, to accurately anticipate your customers' likely responses. Managers must accept that there may be irrational or emotional responses to a price change that have been made very rationally and for good economic reasons. If price changes are associated with changes in costs or with maintaining the business in response to competitive pressures then customers are more likely to perceive price changes as fair. In contrast, however, if these price changes are associated with taking advantage of customers' value, or their lack of price sensitivity, or the lack of competitive alternatives in the market, then they are perceived to be unfair.

The key for managers is to attempt to understand the way in which a price change will be interpreted by the market and to accept the fact that different customers, in different market segments, may well perceive exactly the same price change in an entirely different way. In our field work, for example, we visited the top ten customers for one particular client. The client had recently lowered all their list prices for a particular product line in an attempt to signal to customers that their products were competitive in this marketplace. Yet each customer, when confronted with this price change, developed a completely different interpretation of the price decrease. One customer suggested that the manufacturer must be going out of business, another customer thought the manufacturer anticipated a new competitor in the market, a third customer was convinced that the price change was designed to aid a different distributor at their expense. These very different interpretations could often be attributed to what was happening in each customer's particular market. For example, the first customer was going out of business, the second was facing a new market entrant, and the third was struggling to negotiate with the manufacturer. Looking into your customers' environments and understanding their issues from their perspective is often critical in understanding how to communicate a price change. 
Another way that customer interpretations of prices are encountered is as "norms". Sometimes the real cost of a price change is that it creates a precedent or a market expectation for future price changes. Pricing actions in one period therefore have repercussions in future periods since they create a norm that is hard to change. Some managers describe cutting prices as "feeding the animal." A classic example of this is the pressure most managers experience in using sales promotions to increase sales. Eventually the overuse of these promotions can create customer norms in which a sales promotion is expected, indeed demanded, before purchase will occukxix. These customer norms are also a cause of falling prices in the computer and other high technology industries today. Conversely, customers can also develop norms that expect increasing rather than decreasing price changes. One company we studied had been raising prices for years, but now wanted to lower prices. When confronted with the managerial suggestion to lower prices, the sales force asked management to raise prices instead. In effect, price increases had become the norm for their industry and the sales managers were afraid of the effect that changing this norm would have on future price changes and negotiations with their customers. Managers can often form their own interpretation of whether a price change is good or bad in isolation from the market. In reality, all price changes are interpreted by customers through a lens of their existing pricing norms.

Too often firms concentrate on the level of the price change at the expense of the explanation behind it. At a minimum this suggests that firms should invest in continually monitoring the pricing norms that are manifest in the market. It also suggests that firms should allocate resources to communicating with customers in order to deliver a coherent message when changing prices. As the examples above illustrate, it is critical for firms to communicate the logic behind their price changes so that customers can make sense of these changes in the way that the firm intended. Finally, in some situations an understanding of customer interpretations of price changes may also constrain a firm to not change price. Coke and Amazon.com have both publicly stated that, based on their past experiences, they would not change prices in this manner again. 


\section{Shatter the Myth of Costless Pricing Within Your Organization}

In response to the effectiveness of Walmart's every day low pricing strategy Sears launched their version called "Everyday Fair Pricing". Yet adjusting to this new pricing format imposed substantial costs on Sears. Externally, they needed to communicate this change to customers who had prevailing price norms related to Sears existing pricing policies. The communication task turned out to be more difficult and expensive than they had expected. There were serious customer concerns with the apparent fairness of the new pricing scheme and these concerns were exacerbated by competitors like J.C. Pennys who ran ads asking consumers: "If Sears are pricing fairly now, how were they pricing to you over the last one hundred years?". Internally Sears had to change their systems, knowledge, and culture to be able to undertake EDFP effectively. In the end Sears had to drop Everyday Fair Pricing, despite having paid for many of the costs that this change in pricing strategy imposed upon them. Had Sears realized that in order to successfully change their pricing format they would have to first incur these customer and managerial costs, perhaps they would have been able to avoid this pricing fiasco.

If we have succeeded in our quest, you leave this paper with a different view of pricing than when you began. First, you understand that pricing is all about price changes, and that these changes are often simultaneously subtle and substantial. This awareness alone will help you avoid the kinds of mistakes that Amazon.com, Coca-Cola, and Sears have experienced. Second, you leave with a framework to deal with the dynamics of changing prices. This framework incorporates customer interpretations of price changes, an awareness of the organizational costs of price changes, investments in future pricing processes, and an understanding of the role that supply chains play in price change strategy. The framework can be used at the tactical level to improve the specific price changes you make, at the managerial level to decide whether or not to make a particular price change at all, and at the strategic level to determine what price adjustment processes should be invested in to improve pricing effectiveness in the future.

We challenge you to shatter the myth of costless pricing in your organization. 


\section{Footnotes}

${ }^{\mathrm{i}}$ Akshay R. Rao, Mark E. Bergen and Scott Davis, "How to Fight a Price War", Harvard Business Review, March-April, 2000.

${ }^{i i}$ Rajiv Lal \& Mitchell Kristofferson, "Value Pricing at Procter \& Gamble (B)", HBS Case Study M284B.

iii Nicholas G. Carr, "Managing in the Euro Zone”, HBS, Product Number 99111.

${ }^{\text {iv }}$ Direct evidence of the costs of changing prices in the retail sector and in industrial markets has been documented in: a) Daniel Levy, Mark Bergen, Shantanu Dutta, and Robert Venable. “The Magnitude of Menu Costs: Direct Evidence from Large U.S. Supermarket Chains.” Quarterly Journal of Economics 112 (August 1997), 791-825 and b) Mark Zbaracki, Mark Ritson, Daniel Levy, Shantanu Dutta and Mark Bergen (2001), "Managerial and Customer Costs of Price Adjustment: Direct Evidence from Industrial Markets", forthcoming, Review of Economics and Statistics. Other evidence on costs of price adjustment includes work by Alan Blinder et. al. Asking About Prices: A New Approach to Understanding Price Stickiness. New York, NY: Russell Sage Foundation, 1998

${ }^{\mathrm{v}}$ Some examples of theoretical work that has articulated the costs of price adjustment include: a) Laurence Ball and N. Gregory Mankiw “A Sticky-Price Manifesto.” Carnegie-Rochester Conference Series on Public Policy (1994), 127-152. and b) Julio J. Rotemberg, "Sticky Prices in the United States.” Journal of Political Economy 90 (1982), 1187-1211.

${ }^{\text {vi }}$ Ibid (Levy, Bergen and Dutta 1997). 
vii Ibid (Ball and Mankiw 1994, p. 142).

viii These suggestions are based on the field research undertaken by Mark Zbaracki, Mark Ritson, Daniel Levy, Shantanu Dutta and Mark Bergen (2001), "Managerial and Customer Costs of Price Adjustment: Direct Evidence from Industrial Markets”, Review of Economics and Statistics, forthcoming.

${ }^{\text {ix }}$ Ibid (Ball and Mankiw 1994, p. 142).

${ }^{\mathrm{x}}$ Ibid (Zbaracki et. al., forthcoming).

${ }^{x i}$ Alvin J. Silk and Steven C. Michael, “American Airlines’ Value Pricing (A)”. HBS Case Study: 0-594-001.

${ }^{x i i}$ Alan Chen et al, "A Behavioral Explanation for the Use of Payments During Hyperinflation", University of Minnesota Working Paper 326-B.

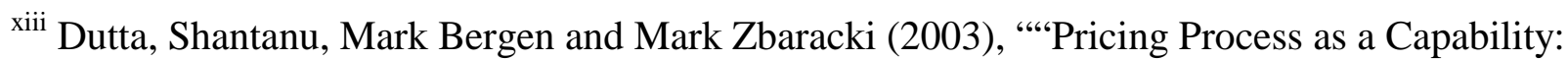
A Resource Based Perspective”, 2003, Strategic Management Journal.

${ }^{\text {xiv }}$ Mark Zbaracki, Mark Ritson, Daniel Levy, Shantanu Dutta and Mark Bergen (2002), "Pricing as a Strategic Capability", Sloan Management Review.

${ }^{\mathrm{xv}}$ We find exactly this pattern of small wholesale price adjustments in "Asymmetric Wholesale Price Adjustment: Downstream Menu Costs and Upstream Channel Pricing” (Sourav Ray, Haipeng Chen, Mark Bergen and Daniel Levy), currently under revise and resubmit at Marketing Science.

${ }^{x v i}$ Coca-Cola's New Vending Machine (A): Pricing to Capture Value or Not? HBS 9-500-068; Los Angeles Times 2 Oct 2000. 
${ }^{\text {xvii }}$ Ibid Nicholas G. Carr

xviii Richard Thaler, Daniel Kahneman and Jack Knetsch, "Fairness as a Constraint on ProfitSeeking: Entitlements in the Market", American Economic Review, 1986.

${ }^{x i x}$ The Double Jeopardy of Sales Promotions, John Phillip Jones, Harvard Business Review, 1990 (Sept / Oct), p. 2-9. 